\begin{tabular}{|l|l|l||}
\hline \multicolumn{2}{|c|}{ PublisherInfo } \\
\hline \hline PublisherName & $:$ & BioMed Central \\
\hline \hline PublisherLocation & $:$ & London \\
\hline \hline PublisherImprintName & $:$ & BioMed Central \\
\hline \hline
\end{tabular}

\title{
Radish correlations and constraints
}

\begin{tabular}{|l|l|l||}
\hline \multicolumn{2}{|c|}{ ArticleInfo } \\
\hline \hline ArticleID & $:$ & 4648 \\
\hline \hline ArticleDOI & $:$ & $10.1186 /$ gb-spotlight-20021202-01 \\
\hline \hline ArticleCitationID & $:$ & spotlight-20021202-01 \\
\hline \hline ArticleSequenceNumber & $:$ & 314 \\
\hline \hline ArticleCategory & $:$ & Research news \\
\hline ArticleFirstPage & $:$ & 1 \\
\hline \hline ArticleLastPage & $:$ & 2 \\
\hline \hline & & RegistrationDate : 2002-12-2 \\
\hline ArticleHistory & $:$ & OnlineDate \\
\hline \hline ArticleCopyright & $:$ & BioMed Central Ltd2002-12-2 \\
\hline \hline ArticleGrants & $:$ & \\
\hline \hline ArticleContext & $:$ & 130593311 \\
\hline \hline
\end{tabular}




\section{Jonathan B Weitzman}

Email: jonathanweitzman@hotmail.com

Genetic correlations between two phenotypic traits can impose constraints on evolutionary change. Genetic correlation may be caused by pleiotropy, in which one genetic locus affects both traits, or by linkage disequilibrium, in which evolution maintains a non-random association between alleles at two distinct loci. In the November 28 Nature Jeffrey Conner from Michigan State University describes correlations and constraints that influence the evolution of floral traits (Nature 2002, 420:407-410). Conner studied six traits in a natural population of wild radish, Raphanus raphanistrum, an obligate outcrosser. After nine generations of random mating (that is, nine episodes of recombination), there were no significant changes in the genetic correlations between floral traits, implying that pleiotropy is the underlying genetic mechanism responsible for the correlations.

\section{References}

1. Nature, [http://www.nature.com]

2. Michigan State University, [http://www.msu.edu]

3. Tests for major genes affecting quantitative traits in wild radish, Raphanus raphanistrum. 